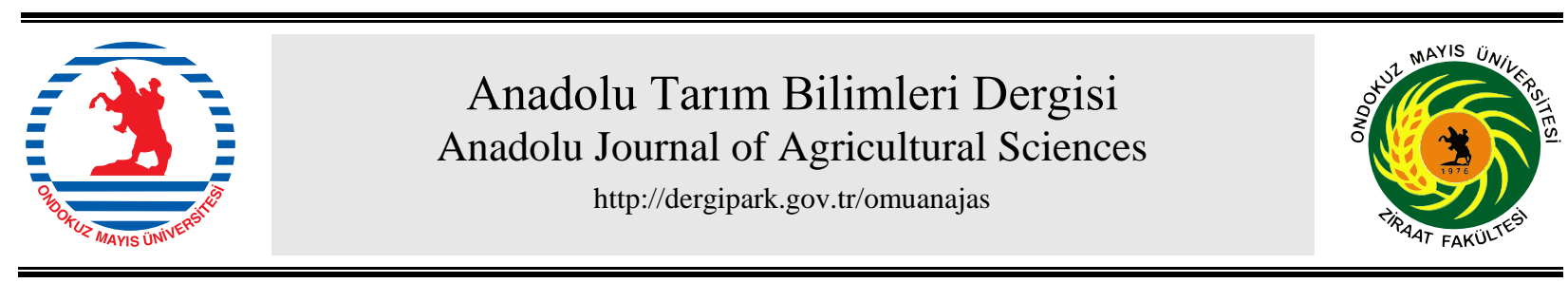

\title{
Araştırma/Research
}

Anadolu Tarım Bilim. Derg./Anadolu J Agr Sci, 34 (2019)

ISSN: 1308-8750 (Print) 1308-8769 (Online) doi: $10.7161 /$ omuanajas.522390

\section{Türkiye'de mercimek piyasasının ekonomik analizi ve pazarlama marjları}

\author{
Uğur Küzeci $^{\mathrm{a} *}$, Vedat Dağdemir ${ }^{\mathrm{b}}$, Tevhit Kahraman ${ }^{\mathrm{a}}$ \\ ${ }^{a}$ Erzincan Binali Ylldırım Üniversitesi Meslek Yüksekokulu - Erzincan \\ ${ }^{b}$ Atatürk Üniversitesi Ziraat Fakültesi Tarım Ekonomisi Bölümü - Erzurum. \\ *Sorumlu yazar/Corresponding author: ukuzeci@mynet.com
}

Geliş/Received 05/02/2019 Kabul/Accepted 24/09/2019

\begin{abstract}
ÖZET
Bu çalışmada Türkiye'de yeşil ve kırmızı mercimeğin üretici-tüketici fiyatları ve pazarlama yapısı incelenmiştir. 2003-2017 yılları arasında üretim-tüketim, dış ticaret, fiyat dalgalanmaları ve pazarlaması üzerinde durulmuştur. Türkiye'de ekim alanları ve üretim miktarında düşüş olmasına karşıllk verimde artı̧̧ olduğu tespit edilmiştir. İthalatta yıllara göre artış, ihracatta ise azılış olmuştur. Yeşil ve kırmızı mercimeğin cari ve reel fiyatlara göre pazarlama marjları hesaplanmış, aracılar eline geçen oranın yükseldiği gözlemlenmiştir. Cari fiyatlara göre üretici ve tüketici zincirleme indeksleri hesaplanarak yıllık enflasyon oranları ile karşılaştırılmıştır. Mercimek üretici fiyatlarının çoğu yılda enflasyon oranının altında kaldığı tespit edilmiştir. Kırmızı mercimek ile ilgili arz ve talep modelleri tahmin edilmiş ve istatistiki olarak yorumlanmıştır. Sonuçta kırmızı mercimek üretim miktarı üzerine üretici reel fiyatlarının, kırmızı mercimek tüketim miktarı üzerine ise tüketici reel fiyatlarının etkili olduğu belirlenmiştir. Kırmızı mercimek arz ve talep fonksiyonlarına göre arz elastikiyeti 0.769 , talep elastikiyeti 0.448 bulunmuştur.
\end{abstract}

\section{Marketing margins and economic analysis of the lentil market in Turkey}

\section{ABSTRACT}

In this study, the producer and consumer prices and marketing structure of green and red lentils in Turkey were examined. Between 2003 and 2017, production - consumption, foreign trade, price fluctuations and marketing have been emphasized. The reduction in amount of acreage and production in Turkey in response to the yield was found to increase. There was an increase in imports compared to years and a decrease in exports. The marketing margins of green and red lentils were calculated according to the current and real prices, and it was observed that the ratio of intermediaries increased. According to current prices, producer and consumer chain indexes are calculated and compared with annual inflation rates. Lentil producer prices were found to be below the inflation rate in most of the years. Supply and demand models related to red lentils are estimated and interpreted statistically. As a result, it has been determined that producer real prices on red lentil production quantity and consumer real prices on red lentil consumption amount are effective. According to the supply and demand functions of red lentils, supply elasticity was 0.769 and demand elasticity was 0.448 .

Anahtar Sözcükler: Yeşil mercimek Kırmızı mercimek Pazarlama yapisi Fiyat dalgalanmaları
Keywords: Green lentils Red lentils Marketing structure Price fluctuations

\section{Giriş}

Baklagiller familyasına ait türler tüm dünya için çok önemli bitkisel protein kaynağıdırlar. Bu ürünler, "Dünya Gıda Programı" ve diğer "Gıda Yardım Girişimleri” kapsamında genel gıda sepetlerinin önemli bir parçası olarak kullanılmaktadırlar. Hayvansal proteinler, besin madde içeriği bakımından insan beslenmesinde bitkisel proteinlerden daha uygun bulunmakla birlikte, baklagiller zengin protein ve aminoasit içerikleriyle hayvansal proteinlerle k1yaslanabilir seviyededir (Kaya, 2010).

Bakliyat grubunu oluşturan ürünler ilk çağlardan beri insanlar tarafindan kültürü yapılarak üretilen besin gruplarından birisi olup insan beslenmesinde büyük önem taşımaktadırlar (Kılıç, 1997). Kuru baklagillerden olan mercimek birçok yönden öneme sahip bir bitkidir. Tahıllara göre daha yüksek protein miktarına sahiptir ve iyi bir protein kaynağıdır. Vitamin ve mineral maddeler 
bakımından zengin olup tahıllarla beraber tüketildiğinde amino asit dengesini iyileştirmektedir (Pellet, 1988).

Mercimek kurak bölgelerde ekim nöbetine girerek hem üreticiye hem de ülke ekonomisine ek gelir sağlayan bir bakliyattır. Dünyada mercimek üretimi toplam baklagiller üretiminin $\% 4,9$ 'unu oluşturmaktadır. Dünyada mercimek üretimi 50 ülkede yapılmakta olup toplam ticaret hacmi yaklaşı 6,5 milyar dolardır (Anonim, 2013). Mercimek üretiminde söz sahibi ülkelerin üretici fiyatlarına bakıldığında, en yüksek fiyatın Türkiye'de, en düşük fiyatın ise Hindistan'da olduğu görülmektedir. 2016 yılında mercimek üretici fiyatının Türkiye'de 836 \$/ton, Kanada'da 625\$/ton, ABD 611 \$/ton, Hindistan'da ise 469 \$/ton olduğu görülmektedir (FAO, 2018).

Dünyada, 2016 yllında 5,5 milyon hektarlık bir alanda yaklaşık 6,4 milyon ton mercimek üretilmiş ve ortalama verim 1,16 ton/da olmuştur. 2016 y1lı itibariyle 3,2 milyon tonluk üretim ile Kanada dünya mercimek üretiminin \%50,0'ını karşılayarak ilk sırada yer alırken, Hindistan 1,05 milyon ton üretim yaparak dünya mercimek üretiminin \%16,0'ını karşılayarak ikinci sirada yer almaktadır. Türkiye ise 365 bin tonluk üretim ve \%6,0 pay ile üçüncü sıradadır (FAO, 2018).

Dünya genelinde üretilen bakliyatın yaklaşık \%84,0'1 ülkelerin iç talebini karşılamaya yöneliktir. Geriye kalan \%16,0'l1k kısım ise dünya ticaretine dâhil olmaktadır (Anonim, 2017). Türkiye'de 2016 yll verilerine göre her yıl işlenen tarım alanlarının yaklaşık $\% 3,91^{\prime}$ lik bölümünde baklagiller yetiştirilmektedir. 2016 yılı itibariyle baklagiller yaklaşık 7,15 milyon dekar alanda ekili olup 1,08 milyon ton üretim gerçekleşmiştir. Toplam baklagiller ekim alanının yaklaşık \%35,2'lik (\%33,0'1 kırmızı mercimek, $\% 2,2^{\prime}$ lik kısmı ise yeşil mercimek) kısmında mercimek üretimi gerçekleşmiştir (TÜiK,2018). 2016 yllında toplam 365 bin ton mercimek üretilmiş olup bunun 20 bin tonu $(\% 5,5)$ yeşil, 345 bin tonu $(\% 94,5)$ ise kırmızı mercimekten oluşmaktadır. 2017 yılı verilerine göre ise Türkiye'de her yıl işlenen tarım alanlarının yaklaşık $\% 3,90$ 'lık bölümünde baklagiller yetiştirilmektedir (TUIK, 2018). 2017 y1lı itibariyle baklagiller, yaklaşık 7,9 milyon dekar alanda ekili olup, 1,16 milyon ton üretim gerçekleştirilmiştir. Toplam baklagiller ekim alanının \%36,7'sini $\quad(\% 34,0$ 'lık kısmı kırmızı mercimek,\%3,7'lik kısmı ise yeşil mercimek) mercimek ekim alanı oluştururken, toplam baklagiller üretim miktarının \%37,1'ini (\%34,3'lük kısmı kırmızı mercimek, \%2,8'lik kısmı ise yeşil mercimek) mercimek üretimi oluşturmaktadır (TUIK, 2018). Türkiye'de mercimek üretiminin 400 bin tonu $(\% 93,0)$ kırmızı, 30 bin tonu $(\% 7,0)$ ise yeşil mercimektir.

$\mathrm{Bu}$ çalışmada, mercimeğin üretici-tüketici fiyatları dikkate alınarak, bunların yıllar itibariyle göstermiş olduğu dalgalanma oranları belirlenmiştir. Yine üretici ve tüketici cari ve reel fiyatlarına göre pazarlama marjları tespit edilmiştir. Üretim, ihracat ve ithalat verileri kullanılarak tüketim miktarları tespit edilmiştir. Cari mercimek fiyatlarından üretici ve tüketici zincirleme indeksleri hesap edilmiş, bu indekslerin farklarıla yıllık enflasyon oranları arasında karşılaştırma yapılmıştır.

\section{Materyal ve Metot}

\subsection{Materyal}

$\mathrm{Bu}$ çalışmada kırmızı ve yeşil mercimeğin üretim miktarı, ekim alanları ve verim miktarları Türkiye İstatistik Kurumuna (TUİK) ait, kırmızı ve yeşil mercimeğin üretici fiyatları (çiftçi eline geçen), perakende fiyatları (tüketici) ve ithalat-ihracat miktarları ise Türkiye İstatistik Kurumu (TUIK), Food and Agriculture Organization (FAO), Türkiye Odalar ve Borsalar Birliği (TOBB), Türkiye İhracatçılar Meclisi (TIM), Tarımsal Ekonomi ve Politika Geliştirme Enstitüsüne (TEPGE) gibi kurumlardan elde edilmiştir. $\mathrm{Bu}$ veriler 2003-2017 dönemine ait yıllık verileridir. Ayrıca çeşitli yayın ve kaynaklardan da yararlanılmıştır.

\subsection{Metot}

Kırmızı ve yeşil mercimek üretici ve tüketici cari fiyatları, üretici ve tüketici fiyat indeksleri $(2003=100)$ dikkate alınarak reel fiyatlara dönüştürülmüsstür. Fiyatlardaki yıldan yıla dalgalanmalar, önce mutlak değerler halinde gösterilmiş, daha sonra karşılaştırılan iki yıldan, ilkinin yüzdesi halinde ifade edilmiştir. Elde edilen yüzde oranlarının işaretleri dikkate alınmadan ortalamalar hesaplanmıştır (Dağdemir ve Birinci,1999; Altundağ ve Güneş 1992). Çiftçi eline geçen fiyatlar (üretici fiyatları) ile tüketicinin ödediği fiyatlar arasındaki fark "Pazarlama Marjı" olarak hesaplanmıştır (Aşkan ve Dağdemir, 2015 ).

Zincirleme fiyat indeksi hesap edilirken 2003-2017 yıl aralığı ele alınarak üretici ve tüketici cari fiyatları yıldan yıla karşılaştırmalı olarak hesap edilmiştir. Zincirleme fiyat indeksinde temel yıl yoktur. Herhangi bir yıla ait indeks, bir önceki yılın fiyatı temel alınarak hesaplanmıştır. Zincirleme fiyat indeksinde asıl amaç, fiyatın zamanda yıllık değişmelerini incelemek, yani bir sonraki yılda bir önceki yıla göre fiyatların ne oranda arttığını ya da azaldığını belirlemektir (Dağdemir,1998).

Çiftçi eline geçen fiyat ile kırmızı mercimek üretimi arasındaki ilişki incelenirken, belli bir yıl fiyatının (t) üretim üzerindeki etkisinin ancak bir y1l sonra (t-1) ortaya çıkabileceği dikkate alınarak, kırmızı mercimek üretim serisi aynen korunmuş, fiyat serisi bir yıl geriye kaydırılarak analiz yapılmıştır.

Türkiye'de toplam mercimek üretiminin \%93'ünü kırmızı mercimek oluşturduğu için sadece kırmızı mercimek arz ve talep modelleri tahmin edilmiştir. Arz ve talep fonksiyonlarıyla ilgili modeller tahmin edilirken, seriler tek tek doğrusal, çift logaritmik ve yarı logaritmik modellerde denenmiştir. Yapılan analizlerde en uygun istatistiki sonuçları veren yarı logaritmik modeller (Log-Lin) kullanılmıştır. Tüm bağımsız değişkenlerdeki fiyatlar reel olarak $(2003=100)$ dikkate alınmıştır. Kurulan modellerde zaman serisi analizlerinde görülen otokorelasyon probleminin olup 
olmadığını anlamak için Durbin-Watson testi uygulanmış ve otokorelasyon probleminin olmadığı anlaşılmıştır.

Kırmızı Mercimek arz fonksiyonu ile ilgili tahmin edilen model formül 1'deki gibidir.

$\log M U_{(t)}: \alpha+\beta_{1} M U F_{(t-1)}+\beta_{2} Y U F_{(t-1)}+\beta_{3} G F_{(t)}$

$+\beta_{4} M F_{(t)}+\epsilon$

MU : Kırmızı Mercimek Üretim Miktarı (ton)

MUF : Kırmızı Mercimek Üretici Reel Fiyatı (₹ $\mathrm{kg}^{-1}$ )

(Çiftçi eline geçen fiyattır.)

YUF : Yeşil Mercimek Üretici Reel Fiyatı (毛 $\mathrm{kg}^{-1}$ )

GF : Gübre Reel Fiyatı (£ ton $^{-1}$ )

MF : Mazot Reel Fiyatı ( $\left(l t^{-1}\right)$

Kırmızı Mercimek talep fonksiyonu ile ilgili tahmin edilen model formül 2'deki gibidir.

$\log M T_{(t)}: \alpha+\beta_{1} M T F_{(t)}+\beta_{2} Y T F_{(t)}+\beta_{3} M G_{(t)}+$ $\beta_{4} N_{(t)}+\epsilon$

MT: Kırmızı Mercimek Tüketim Miktarı (ton) (Üretim + Ithalat-íhracat)

MTF : Kırmızı Mercimek Tüketici Reel Fiyatı (Đ/ kg)
YTF : Yeşil Mercimek Tüketici Reel Fiyatı (Đ/kg)

MG : Milli Gelir (‡/Kişi) (Reel Gelire

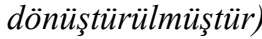

$N$ : Nüfus (kişi)

\section{Bulgular ve Tartıșma}

Türkiye'de mercimek ekim alanı 2017 yılında toplam tarım alanının \% 0.77'sini, toplam baklagiller ekim alanının ise \% 36.7'sini olușturmaktadır. Bu \% $0.77^{\prime}$ lik ekim alanının \% 0.06'sını yeşil mercimek, $\% 0,71$ 'ini ise kırmızı mercimek oluşturmaktadır (TÜİK, 2018). Toplam mercimek üretim alanları içerisinde kırmızı mercimeğin payı \% 86.0 iken yeşil mercimeğin payı \% 14.0’dır (Tablo.1).

2003 yılı ile 2017 yılı karşılaştırılması yapıldığında 15 yılda yeşil mercimek ekiliş alanında \% 62.55, üretim miktarında \% 45.45 düşüş görülürken, verimde \% 44.94'lük bir artış olmuştur. Kırmızı mercimek ekiliş alanında \% 29.13, üretim miktarında \% 17.53 düşüş görülürken, verimde \% 16.41'lik bir artış olmuştur. Yeşil mercimek 15 yıllık verim ortalaması $106.5 \mathrm{~kg} \mathrm{da}^{-1}$ iken kırmızı mercimekte verim ortalaması $147 \mathrm{~kg} \mathrm{da}^{-}$ ${ }^{1}$ dir

(Tablo.1).

Tablo 1. Türkiye'de 2003 - 2017 Yılları Mercimek Ekiliş, Üretim ve Verim Durumu

\begin{tabular}{ccccccc}
\hline & \multicolumn{3}{c}{ Yeşil Mercimek } & \multicolumn{3}{c}{ Kirmızı Mercimek } \\
\cline { 2 - 7 } Y1llar & $\begin{array}{c}\text { Ekim Alanı } \\
(\mathrm{da})\end{array}$ & $\begin{array}{c}\text { Üretim } \\
(\text { ton })\end{array}$ & $\begin{array}{c}\text { Verim } \\
\left(\mathrm{kg} \mathrm{da}^{-1}\right)\end{array}$ & $\begin{array}{c}\text { Ekim Alan1 } \\
(\mathrm{da})\end{array}$ & $\begin{array}{c}\text { Üretim } \\
(\text { ton })\end{array}$ & $\begin{array}{c}\text { Verim } \\
\left(\mathrm{kg} \mathrm{da}^{-1}\right)\end{array}$ \\
\hline 2003 & 620000 & 55000 & 89 & 3800000 & 485000 & 128 \\
2004 & 600000 & 60000 & 100 & 3790000 & 480000 & 127 \\
2005 & 532000 & 50000 & 94 & 3867000 & 520000 & 134 \\
2006 & 454625 & 42326 & 93 & 3787075 & 580298 & 153 \\
2007 & 323083 & 26803 & 83 & 3572328 & 508378 & 142 \\
$2008 *$ & 276977 & 24827 & 90 & 2909766 & 106361 & 37 \\
2009 & 255531 & 27131 & 106 & 1893780 & 275050 & 145 \\
2010 & 228922 & 25400 & 111 & 2116000 & 422000 & 199 \\
2011 & 225248 & 25952 & 115 & 1923225 & 380000 & 198 \\
2012 & 226903 & 28000 & 123 & 2147875 & 410000 & 191 \\
2013 & 206783 & 22000 & 106 & 2605000 & 395000 & 152 \\
2014 & 170476 & 20000 & 117 & 2324461 & 325000 & 140 \\
2015 & 163881 & 20000 & 122 & 2074690 & 340000 & 164 \\
2016 & 167617 & 20000 & 119 & 2354743 & 345000 & 147 \\
2017 & 232201 & 30000 & 129 & 2693181 & 400000 & 149 \\
Ort. & 312283 & 31829 & 107 & 2790608 & 398139 & 147 \\
\hline Kayyyyyyy & & & & & &
\end{tabular}

Kaynak: tuik.gov.tr. 2018

*2008 yılında yağışların aşırı düşük olmasından dolayı verim ortalaması diğer yıllara göre düşüktür. 
2003-2017 yılları arasında 15 yılda yeşil mercimek tüketimi \% 21.47 oranında düşüş gösterirken ithalatında artış, ihracatında ise azalış olmuştur. Yeşil mercimek kişi başına tüketiminde yıllara göre azalış olmuş, kişi başına ortalama tüketim $0.72 \mathrm{~kg}$ olarak hesaplanmıştır. 15 yılda kırmızı mercimek tüketimi $\% 76.54$ oranında artı̧̧ göstermiş, ithalat da ve ihracatta da artış olmuştur. Fakat ithalattaki artış çok daha fazla oranda artış göstererek ihracattaki artışı geçmiştir.

Kırmızı mercimek kişi başına tüketiminde yıllara göre artış olmuş, kişi başına ortalama tüketim $5.32 \mathrm{~kg}$ olarak hesaplanmıştır. 2017 y1lında mercimek toplam tüketiminin \% 10.7'si yeşil mercimek, \% 89.3'ü ise kırmızı mercimekten oluşmaktadır (Tablo.2). Türkiye'de 2003-2017 yılları arasında nüfusun \% 20.28 arttığ 1 (TUIK, 2018) düşünüldüğünde hem yeşil hem de kırmızı mercimekte tüketim açığı ithalatla kapatılmıştır.

Yeşil mercimekte ihracatın ithalatı karşılama oranı 2003 yılında \% 15 düzeyindeyken bu rakam 2017 yılında $\% 5$ düzeyine düşmüştür. Kırmızı mercimekte ihracatın ithalatı karşılama oranı 2003 yılında \% 1200 düzeyindeyken bu rakam 2017 yılında \% 70 düzeyine düşmüştür (Tablo.2).

Genel olarak mercimek fiyatlarının artış eğiliminde olduğu görülmektedir. Özellikle kırmızı mercimek üretici fiyatının 2009 ve sonrası yıllardaki artışı, tüketici fiyatlarının da artmasında etkili olmuştur. Kırmızı mercimek fiyatlarında en fazla artış 2008 yılında gerçekleşmiş ve bir önceki yıla göre \% 230 oranında artış göstermiştir. Bu artış tüketici fiyatının da artmasına neden olarak \%260 oranında artışla 4,17 € kg ${ }^{1}$ olmuştur. 2017 yılında bir önceki y1la göre kırmızı mercimek üretici fiyatındaki \% 5.5 oranında, yeşil mercimekte ise \% 8 oranında artmıştır. Bu artışın tüketici fiyatlarına etkisi ise kırmızı mercimekte \%33 oranında yeşil mercimekte \% 11.5 oranında artışa neden olmuştur (Tablo.3).

Tüketicinin bir kg mercimeğe ödediği fiyat ile bir kg mercimeğe karşıllk çiftçi eline geçen fiyat arasındaki fark pazarlama marjını vermektedir. Yani, aracıların eline geçen değer kastedilmektedir. Cari fiyatlar dikkate alındığında, yıllara göre aracıların eline geçen yüzde oranlar yeşil mercimekte \% 14-\% 56, çiftçi eline geçen oranlar ise \% 44-\% 86 arasında değişmektedir. Kırmızı mercimekte aracı eline geçenle yüzde oranlar \% 27-\% 68 oranında, çiftçi eline geçen yüzde oranlar ise \% 32-\% 73 arasindadır (Tablo 3).

Mercimek reel fiyatlarını incelediğimizde 2003 yılında yeşil mercimeğin üretici fiyatı $1,16 \mathrm{~kg}^{-1}$ iken 2017 yılında enflasyondan arındırılmış fiyatı 1.04 € $\mathrm{kg}^{-1}$ 'dır. Enflasyondan arındırılmış fiyatlar mukayese edildiğinde üreticinin 15 ylllık periyotta yeşil mercimek fiyatları üzerinden satın alma gücü $\% 10.35$ oranında azalmıştır.

Kırmızı mercimek reel fiyatlarını incelediğimizde 2003 yılında kırmızı mercimeğin üretici fiyatı 1,10 $£ \mathrm{~kg}^{-1}$ iken 2017 yılında enflasyondan arındırılmış fiyatı $0.93 € \mathrm{~kg}^{-1}$ dır. Enflasyondan arındırılmış fiyatlar mukayese edildiğinde üreticinin on beş ylllık periyotta kırmızı mercimek fiyatları üzerinden satın alma gücü $\% \quad 8.5$ oranında azalmıştır. Tüketici fiyatlarını incelediğimizde ise 2003 yılında $1.5 \mathrm{f} \mathrm{kg}^{-1}$ olan kırmızı mercimek tüketici fiyatı 2017 yılında enflasyondan arındırılmış fiyatı $2.68 € \mathrm{~kg}^{-1}$ dır. Enflasyondan arındırılmış fiyatlar mukayese edildiğinde tüketicinin 15 yıllık periyotta kırmızı mercimek fiyatları üzerinden satın alma gücü \% 44 oranında azalmıştır. Üreticinin 1 kg kırmızı mercimek üretiminde elde ettiği kazanç 15 yılda \% 8.5 azalırken, tüketicinin $1 \mathrm{~kg}$ kırmızı mercimek satın almak için ödediği fiyat ise \%44 oranında artmıştır.

Reel fiyatlar dikkate alındığında, yıllara göre aracıların eline geçen yüzde oranlar yeşil mercimekte $\%$ 12-\% 58, çiftçi eline geçen oranlar ise \% 42-\% 88 arasında değişmektedir. Kırmızı mercimekte aracı eline geçenle yüzde oranlar \% 27-\% 69 oranında, çiftçi eline geçen yüzde oranlar ise \% 31-\% 73 arasındadır (Tablo 4).

Mercimek cari fiyatlarına göre üretici ve tüketici zincirleme indeksleri hesaplanmış ve bunların yıllara göre farkları alınarak enflasyon oranları ile karşılaş̧ırılmıştır. $\mathrm{Bu}$ karşılaştırma sonucunda, yeşil mercimekte üretici eline geçen fiyatların 2004, 2006, 2010, 2011, 2013, 2014, 2017 yıllarında, kırmız1 mercimekte ise 2004, 2005, 2006, 2007, 2009, 2010, 2012, 2013, 2017 yillarında enflasyon oranının altında kaldığı tespit edilmiştir. Bu yıllardaki fiyatlar üreticinin aleyhine olmuştur (Tablo 5).

Tüketicinin durumunu incelendiğimiz zaman kırmızı mercimekte 2006, 2007, 2008, 2009, 2010, 2011, 2012, 2013 ve 2016 yllarında tüketicinin satın alma gücü artarken diğer yıllarda ise satın alma gücü düşmüştür. Yeşil mercimekte 2004, 2006, 2008, 2012, 2013 ve 2015 yıllarında satın alma gücü artarken diğer y1llarda ise düşmüştür.

Kırmızı mercimek arz fonksiyonunu ile ilgili olarak tahmin edilen modelde tespit edilen işaretlere göre, kırmızı mercimek üretimi ile kırmızı mercimek üretici reel fiyatı arasında doğru bir ilişki, yeşil mercimek üretici reel fiyatı arasında ise ters bir ilişkinin bulunduğu görülmektedir. Yine kırmızı mercimek üretimi ile gübre reel fiyatı ve mazot reel fiyatı arasında doğru bir ilişkinin olduğu görülmektedir. Bu ekonomik teoriye uymayan bir durumdur. Zaman serisi verilerinin kullanılması sonucu katsayıların işaretlerinde ekonomik teoriye ters sonuçlar da çıkabilmektedir. Yapılan F testine göre kırmızı mercimek arz fonksiyonu için tahmin edilen model $\% 10(\mathrm{P}=0,072)$ önem seviyesinde istatistiki olarak anlamlı bulunmuştur. Yine bağımsız değişkenlerden kırmızı mercimek üretici reel fiyatı $\% 5$ önem seviyesinde istatistiki olarak önemli, diğer bağımsız değişkenlerin önemsiz olduğu tespit edilmiştir. $\mathrm{Bu}$ durum kırmızı mercimek üretiminde kırmızı mercimek üretici reel fiyatının etkili olduğunu göstermektedir. 
Tablo 2. Türkiye'de 2003-2017 Yılları Arası Mercimek Üretim, Tüketim ve Pazarlaması

\begin{tabular}{|c|c|c|c|c|c|c|c|c|c|c|}
\hline \multirow[b]{2}{*}{ Yillar } & \multicolumn{5}{|c|}{ Yeşil Mercimek } & \multicolumn{5}{|c|}{ Kırmızı Mercimek } \\
\hline & $\begin{array}{l}\text { Üretim } \\
\text { (Ton) }\end{array}$ & $\begin{array}{c}\text { Tüketim } \\
\text { (Ton) }\end{array}$ & $\begin{array}{l}\text { Kişi Başı } \\
\text { Tüketim } \\
\left(\mathrm{kg} \mathrm{y}_{1} \mathrm{l}^{-1}\right)\end{array}$ & $\begin{array}{l}\text { İthalat } \\
\text { (Ton) }\end{array}$ & $\begin{array}{l}\text { İhracat } \\
\text { (Ton) }\end{array}$ & $\begin{array}{l}\text { Üretim } \\
\text { (Ton) }\end{array}$ & $\begin{array}{l}\text { Tüketim } \\
\text { (Ton) }\end{array}$ & 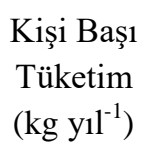 & $\begin{array}{l}\text { İthalat } \\
\text { (Ton) }\end{array}$ & $\begin{array}{c}\text { İhracat } \\
\text { (Ton) }\end{array}$ \\
\hline 2003 & 55000 & 69257 & 1.03 & 16792 & 2535 & 485000 & 287468 & 4.28 & 16909 & 214441 \\
\hline 2004 & 60000 & 76620 & 1.13 & 18520 & 1900 & 480000 & 316272 & 4.65 & 5557 & 169285 \\
\hline 2005 & 50000 & 64137 & 0.93 & 15733 & 1596 & 520000 & 467660 & 6.79 & 64281 & 116621 \\
\hline 2006 & 42326 & 53528 & 0.77 & 12709 & 1507 & 580298 & 349349 & 5.01 & 69071 & 300020 \\
\hline 2007 & 26803 & 52917 & 0.75 & 27449 & 1335 & 508378 & 354379 & 5.02 & 30979 & 184978 \\
\hline 2008 & 24827 & 37435 & 0.52 & 14843 & 2235 & 106361 & 229390 & 3.21 & 191683 & 68654 \\
\hline 2009 & 27131 & 52207 & 0.72 & 25871 & 795 & 275050 & 288279 & 3.97 & 141541 & 128312 \\
\hline 2010 & 25400 & 42941 & 0.58 & 18720 & 1179 & 422000 & 437740 & 5.94 & 210289 & 194549 \\
\hline 2011 & 25952 & 41629 & 0.56 & 17445 & 1768 & 380000 & 476965 & 6.38 & 309561 & 212596 \\
\hline 2012 & 28000 & 51027 & 0.67 & 24349 & 1322 & 410000 & 381393 & 5.04 & 168806 & 197413 \\
\hline 2013 & 22000 & 52068 & 0.68 & 31538 & 1470 & 395000 & 415934 & 5.43 & 199476 & 178542 \\
\hline 2014 & 20000 & 50882 & 0.65 & 32493 & 1611 & 325000 & 444739 & 5.72 & 303154 & 183415 \\
\hline 2015 & 20000 & 45370 & 0.58 & 27080 & 1710 & 340000 & 433941 & 5.51 & 313161 & 219220 \\
\hline 2016 & 20000 & 39620 & 0.50 & 21742 & 2122 & 345000 & 438732 & 5.50 & 337500 & 243768 \\
\hline 2017 & 30000 & 54385 & 0.67 & 25801 & 1416 & 400000 & 507495 & 6.28 & 371426 & 263931 \\
\hline Ort. & 31829 & 52268 & 0.72 & 22072 & 1633 & 400672 & 385733 & 5.32 & 166424 & 181363 \\
\hline
\end{tabular}

Kaynak: Orijinal hesaplamalar. 
Tablo 3. Türkiye'de 2003-2017 Yılları Arasında Cari Fiyatlara Göre Mercimeğin Pazarlama Marjları.

\begin{tabular}{|c|c|c|c|c|c|c|c|c|c|c|}
\hline \multirow{2}{*}{ Yillar } & \multicolumn{5}{|c|}{ Yeşil Mercimek } & \multicolumn{5}{|c|}{ Kırmızı Mercimek } \\
\hline & $\begin{array}{l}\text { Üretici } \\
\text { Fiyatları } \\
\left(€ \mathrm{~kg}^{-1}\right)\end{array}$ & $\begin{array}{l}\text { Tüketici } \\
\text { Fiyatları } \\
\left(£ \mathrm{~kg}^{-1}\right)\end{array}$ & $\begin{array}{c}\text { Pazarlama } \\
\text { Marji }\end{array}$ & $\begin{array}{c}\text { Üretici Eline } \\
\text { Geçen } \\
(\%)\end{array}$ & $\begin{array}{c}\text { Aracı Eline } \\
\text { Geçen } \\
(\%)\end{array}$ & $\begin{array}{l}\text { Üretici } \\
\text { Fiyatları } \\
\left(€ \mathrm{~kg}^{-1}\right)\end{array}$ & $\begin{array}{l}\text { Tüketici } \\
\text { Fiyatları } \\
\left(€ \mathrm{~kg}^{-1}\right)\end{array}$ & $\begin{array}{c}\text { Pazarlama } \\
\text { Marji }\end{array}$ & $\begin{array}{c}\text { Üretici Eline } \\
\text { Geçen } \\
(\%)\end{array}$ & $\begin{array}{c}\text { Aracı Eline } \\
\text { Geçen } \\
(\%)\end{array}$ \\
\hline 2003 & 1.16 & 1.74 & 0.58 & 67 & 33 & 1.10 & 1.50 & 0.40 & 73 & 27 \\
\hline 2004 & 1.08 & 1.25 & 0.17 & 86 & 14 & 1.20 & 1.69 & 0.49 & 71 & 29 \\
\hline 2005 & 1.15 & 1.82 & 0.67 & 63 & 37 & 1.23 & 2.04 & 0.81 & 60 & 40 \\
\hline 2006 & 1.09 & 1.30 & 0.21 & 84 & 16 & 1.28 & 1.88 & 0.60 & 68 & 32 \\
\hline 2007 & 1.26 & 2.00 & 0.74 & 63 & 37 & 1.30 & 2.03 & 0.73 & 64 & 36 \\
\hline 2008 & 1.82 & 2.20 & 0.38 & 83 & 17 & 3.00 & 4.17 & 1.17 & 72 & 28 \\
\hline 2009 & 2.00 & 3.40 & 1.40 & 59 & 41 & 1.35 & 4.27 & 2.92 & 32 & 68 \\
\hline 2010 & 2.11 & 3.85 & 1.74 & 55 & 45 & 1.25 & 3.84 & 2.59 & 33 & 67 \\
\hline 2011 & 2.07 & 4.75 & 2.68 & 44 & 56 & 1.68 & 3.56 & 1.88 & 47 & 53 \\
\hline 2012 & 2.14 & 4.15 & 2.01 & 52 & 48 & 1.65 & 3.20 & 1.55 & 52 & 48 \\
\hline 2013 & 2.11 & 4.00 & 1.89 & 53 & 47 & 1.09 & 3.34 & 2.25 & 33 & 67 \\
\hline 2014 & 2.17 & 5.00 & 2.83 & 44 & 56 & 1.83 & 4.50 & 2.67 & 41 & 59 \\
\hline 2015 & 2.64 & 5.25 & 2.61 & 50 & 50 & 2.07 & 5.40 & 3.33 & 38 & 62 \\
\hline 2016 & 3.02 & 6.25 & 3.23 & 48 & 52 & 2.75 & 5.00 & 2.25 & 55 & 45 \\
\hline 2017 & 3.26 & 7.20 & 3.94 & 45 & 55 & 2.90 & 8.00 & 5.10 & 36 & 64 \\
\hline
\end{tabular}

Kaynak: Orijinal hesaplamalar. 
Tablo 4. Türkiye'de 2003-2017 Yılları Arası Reel Fiyatlara Göre Mercimeğin Pazarlama Marjları.

\begin{tabular}{|c|c|c|c|c|c|c|c|c|c|c|}
\hline \multirow[b]{2}{*}{ Yillar } & \multicolumn{5}{|c|}{ Yeşil Mercimek } & \multicolumn{5}{|c|}{ Kırmızı Mercimek } \\
\hline & $\begin{array}{l}\text { Üretici } \\
\text { Fiyatları } \\
\left(€ \mathrm{~kg}^{-1}\right)\end{array}$ & $\begin{array}{l}\text { Tüketici } \\
\text { Fiyatları } \\
\left(£ \mathrm{~kg}^{-1} \text { ) }\right.\end{array}$ & $\begin{array}{c}\text { Pazarlama } \\
\text { Marj1 }\end{array}$ & $\begin{array}{c}\text { Üretici Eline } \\
\text { Geçen } \\
(\%)\end{array}$ & $\begin{array}{c}\text { Aracı Eline } \\
\text { Geçen } \\
(\%)\end{array}$ & $\begin{array}{c}\text { Üretici } \\
\text { Fiyatları } \\
\left(€ \mathrm{~kg}^{-1}\right)\end{array}$ & $\begin{array}{l}\text { Tüketici } \\
\text { Fiyatları } \\
\left(€ \mathrm{~kg}^{-1}\right)\end{array}$ & $\begin{array}{c}\text { Pazarlama } \\
\text { Marji }\end{array}$ & $\begin{array}{c}\text { Üretici Eline } \\
\text { Geçen } \\
(\%)\end{array}$ & $\begin{array}{c}\text { Aracı Eline } \\
\text { Geçen } \\
(\%)\end{array}$ \\
\hline 2003 & 1.16 & 1.74 & 0.58 & 67 & 33 & 1.10 & 1.50 & 0.40 & 73 & 27 \\
\hline 2004 & 0.99 & 1.13 & 0.14 & 88 & 12 & 1.10 & 1.53 & 0.43 & 72 & 28 \\
\hline 2005 & 0.98 & 1.52 & 0.54 & 64 & 36 & 1.05 & 1.70 & 0.65 & 62 & 38 \\
\hline 2006 & 0.85 & 0.99 & 0.14 & 86 & 14 & 0.99 & 1.43 & 0.44 & 69 & 31 \\
\hline 2007 & 0.90 & 1.43 & 0.53 & 63 & 37 & 0.93 & 1.45 & 0.52 & 64 & 36 \\
\hline 2008 & 1.18 & 1.40 & 0.22 & 84 & 16 & 1.94 & 2.65 & 0.71 & 73 & 27 \\
\hline 2009 & 1.22 & 2.13 & 0.91 & 57 & 43 & 0.82 & 2.68 & 1.86 & 31 & 69 \\
\hline 2010 & 1.18 & 2.23 & 1.05 & 53 & 47 & 0.70 & 2.22 & 1.52 & 32 & 68 \\
\hline 2011 & 1.09 & 2.47 & 1.38 & 44 & 56 & 0.88 & 1.85 & 0.97 & 48 & 52 \\
\hline 2012 & 1.03 & 2.04 & 1.01 & 50 & 50 & 0.80 & 1.57 & 0.77 & 51 & 49 \\
\hline 2013 & 0.95 & 1.88 & 0.93 & 51 & 49 & 0.49 & 1.57 & 1.08 & 31 & 69 \\
\hline 2014 & 0.90 & 2.13 & 1.23 & 42 & 58 & 0.76 & 1.92 & 1.16 & 40 & 60 \\
\hline 2015 & 1.01 & 2.12 & 1.11 & 48 & 52 & 0.79 & 2.18 & 1.39 & 36 & 64 \\
\hline 2016 & 1.08 & 2.42 & 1.34 & 45 & 55 & 0.98 & 1.94 & 0.96 & 51 & 49 \\
\hline 2017 & 1.04 & 2.41 & 1.37 & 43 & 57 & 0.93 & 2.68 & 1.75 & 35 & 65 \\
\hline
\end{tabular}

Kaynak: Orijinal hesaplamalar. 
Tablo 5. Türkiye'de Mercimek Cari Fiyatlarına Göre Üretici-Tüketici Zincirleme İndeksleri ve Yıllık Enflasyon Oranları

\begin{tabular}{|c|c|c|c|c|c|c|c|c|c|c|c|c|}
\hline \multirow[b]{2}{*}{ Yillar } & \multicolumn{6}{|c|}{ Yeşil Mercimek } & \multicolumn{6}{|c|}{ Kırmızı Mercimek } \\
\hline & $\begin{array}{c}\text { Üretici } \\
\text { Zincirleme } \\
\text { İndeksi }\end{array}$ & $\begin{array}{c}\text { Üretici } \\
\text { İndeks } \\
\text { Farkı }\end{array}$ & ÜFE & $\begin{array}{l}\text { Tüketici } \\
\text { Zincirleme } \\
\text { İndeksi }\end{array}$ & $\begin{array}{l}\text { Tüketici } \\
\text { İndeks } \\
\text { Farkı }\end{array}$ & TÜFE & $\begin{array}{c}\text { Üretici } \\
\text { Zincirleme } \\
\text { Endeksi }\end{array}$ & $\begin{array}{c}\text { Üretici } \\
\text { İndeks } \\
\text { Fark1 }\end{array}$ & ÜFE & $\begin{array}{l}\text { Tüketici } \\
\text { Zincirleme } \\
\text { İndeksi }\end{array}$ & $\begin{array}{l}\text { Tüketici } \\
\text { Zincirleme } \\
\text { İndeksi }\end{array}$ & TÜFE \\
\hline 2003 & 100.0 & - & 13.9 & 100.0 & - & 18.4 & 100.0 & - & 13.9 & 100.0 & - & 18.4 \\
\hline 2004 & 93.1 & -6.9 & 13.8 & 71.8 & -28.2 & 9.3 & 109.1 & 9.1 & 13.8 & 112.7 & 12.7 & 9.3 \\
\hline 2005 & 106.5 & 6.5 & 2.7 & 145.6 & 45.6 & 7.7 & 102.5 & 2.5 & 2.7 & 120.7 & 20.7 & 7.7 \\
\hline 2006 & 94.8 & -5.2 & 11.6 & 71.4 & -28.6 & 9.7 & 104.1 & 4.1 & 11.6 & 92.2 & -7.8 & 9.7 \\
\hline 2007 & 115.6 & 15.6 & 5.9 & 153.8 & 53.8 & 8.4 & 101.6 & 1.6 & 5.9 & 108.0 & 8.0 & 8.4 \\
\hline 2008 & 144.4 & 44.4 & 8.8 & 110.0 & 10.0 & 10.1 & 230.8 & 130.8 & 8.8 & 205.4 & 5.4 & 10.1 \\
\hline 2009 & 109.9 & 9.9 & 5.9 & 154.5 & 54.5 & 6.5 & 45.0 & -55 & 5.9 & 102.4 & 2.4 & 6.5 \\
\hline 2010 & 105.5 & 5.5 & 8.9 & 113.2 & 13.2 & 6.4 & 92.6 & -7.4 & 8.9 & 89.9 & -10.1 & 6.4 \\
\hline 2011 & 98.1 & -1.9 & 13.3 & 123.4 & 23.4 & 10.5 & 134.4 & 34.4 & 13.3 & 92.7 & -7.3 & 10.5 \\
\hline 2012 & 103.4 & 3.4 & 2.5 & 87.4 & -12.6 & 6.2 & 98.2 & -1.8 & 2.5 & 89.9 & -10.1 & 6.2 \\
\hline 2013 & 98.6 & -1.4 & 7.0 & 96.4 & -3.6 & 7.4 & 66.1 & -33.9 & 7.0 & 104.4 & 4.4 & 7.4 \\
\hline 2014 & 102.8 & 2.8 & 6.4 & 125.0 & 25.0 & 8.2 & 167.9 & 67.9 & 6.4 & 134.7 & 34.7 & 8.2 \\
\hline 2015 & 121.7 & 21.7 & 5.7 & 105.0 & 5.0 & 8.8 & 113.1 & 13.1 & 5.7 & 120.0 & 20.0 & 8.8 \\
\hline 2016 & 114.4 & 14.4 & 9.9 & 119.0 & 19.0 & 8.5 & 132.9 & 32.9 & 9.9 & 92.6 & -7.4 & 8.5 \\
\hline 2017 & 107.9 & 7.9 & 15.5 & 115.2 & 15.2 & 11.9 & 105.5 & 5.5 & 15.5 & 160.0 & 60.0 & 11.9 \\
\hline
\end{tabular}


Tablo 6. Kırmızı Mercimek Arz Fonksiyonu İle İlgili Regresyon Analizi Sonuçları

\begin{tabular}{r|ccccc}
\hline LogMU & Katsayılar & $\begin{array}{c}\text { Standart } \\
\text { Hata }\end{array}$ & $\mathrm{P}(\mathrm{t})$ & $\mathrm{P}(\mathrm{F})$ \\
\hline$\alpha$ & 12.3404 & $* * *$ & 0.6654 & 0.000 & \\
MUF & 0.8573 & $* *$ & 0.2873 & 0.014 & 0.072 \\
YUF & -0.6495 & 0.4141 & 0.148 & \\
GF & 0.0001 & 0.0005 & 0.799 & \\
MF & 0.2535 & & 0.2809 & 0.388 & \\
\hline *: \%10, **:\%5 ve ***:\%1 önem seviyelerinde anlamlıdır.
\end{tabular}

Tablo 7. Kırmızı Mercimek Talep Fonksiyonu İle İlgili Regresyon Analizi Sonuçları

\begin{tabular}{r|ccccc}
\hline LogMT & Katsayilar & $\begin{array}{c}\text { Standart } \\
\text { Hata }\end{array}$ & $\mathrm{P}(\mathrm{t})$ & $\mathrm{P}(\mathrm{F})$ \\
\hline$\alpha$ & 10.6330 & $* * *$ & 1.3198 & 0.000 & \\
MTF & -0.2329 & $*$ & 0.1158 & 0.072 & 0.052 \\
YTF & 0.1790 & 0.1601 & 0.291 & \\
MG & -0.0001 & 0.0003 & 0.632 & \\
$\mathrm{~N}$ & 0.0003 & & 0.0002 & 0.180 & \\
\hline *: \%10, **:\%5 ve ***:\%1 önem seviyelerinde anlamlıdır.
\end{tabular}

Çiftçilere Tarım ve Orman Bakanlığı tarafından mazot ve gübre desteği yapılmaktadır. Tahmin ettiğimiz modelde bu iki girdinin kırmızı mercimek üretiminde etkili olmadığı görülmüştür. Kırmızı mercimek talep fonksiyonu ile ilgili tahmin edilen modelde tespit edilen işaretlere göre, kırmızı mercimek tüketimi ile kırmızı mercimek tüketici reel fiyatı ve milli gelir arasında ters bir ilişki, yeşil mercimek tüketici reel fiyatı ve nüfus arasında ise doğru bir ilişki görülmektedir. Kırmızı mercimek tüketimi ile milli gelir arasında doğru bir ilişki beklenirken ters bir ilişki durumu ortaya çıkmıştır. Kırmızı mercimek kişi başına tüketiminin çok yüksek olmamasından dolayı milli gelirdeki değişmenin tüketim üzerindeki etkisinin azaldığı söylenebilir.

Yapılan $\mathrm{F}$ testine göre kırmızı mercimek talep fonksiyonu için tahmin edilen model \%10 $(\mathrm{P}=0,052)$ önem seviyesinde istatistiki olarak anlamlı bulunmuştur. Yine bağımsız değişkenlerden kırmızı mercimek tüketici reel fiyatı \%10 önem seviyesinde istatistiki olarak önemli, diğer bağımsız değişkenlerin önemsiz olduğu tespit edilmiştir. Bu durum kırmızı mercimek üretiminde kırmızı mercimek tüketici reel fiyatının etkili olduğunu göstermektedir.

\section{Sonuç}

Kırmızı mercimek arz ve talep fonksiyonlarına göre arz elastikiyeti (Ae ) 0.769 , talep elastikiyeti (Te) 0.448 bulunmuştur. Kırmızı mercimekte Ae $>$ Te olduğu için fiyatlar merkezden çevreye doğru uzaklaşmakta genişleyen dalgalanmalar ile devri hareket büyümektedir. $\mathrm{Bu}$ durumda üreticilerin fiyatlardaki değişimlere karşı duyarlılığı tüketicilere göre daha fazla olmaktadır.

Cari ve reel olarak yapılan hesaplamalarda son yıllarda pazarlama marjı hesabında aracılar eline geçen oranın yükseldiği gözlemlenmiştir. Yine ithalatta yıllara göre artış, ihracatta ise azılış olmuştur. Verim yükselmesine rağmen ekiliş alanlarında önemli düşüş yaşanmıştır. İthalata dayalı bir sisteme doğru gidilmekte, aracıların etkisi artmakta, çiftçi eline geçen oran azalmaktadır. Ekiliş alanlarının artırılması için arz modelimizde önemli çıkan üretici fiyatları bazında çiftçinin desteklenmesi gerekmektedir. Zincirleme indeks hesabında da mercimek üretici fiyatları çoğu yılda enflasyon oranının altında kalmıştır. Çiftçinin desteklenmesi ile üretim artacak, ithalat azalacak, çiftçi eline geçen oran da artabilecektir.

\section{Kaynaklar}

Altundağ, S., Güneş, T., 1992. Türkiye'de Patates ve Soğanın Üretim Miktarı ile Fiyat İlişkileri. Ankara Üniversitesi Ziraat Fakültesi Yıllığı. s.52-65.

Anonim, 2013. Baklagil Raporu. GAP UTAEM GÜNCEL. Aralık 2013 yıl:1, sayı:1.

Anonim, 2017. http://www.millermagazine.com/dunyakuru-fasulye nohut-pazar1/.html

Aşkan, E., Dağdemir, V., 2018. Türkiye Sarımsak Piyasasının Ekonomik Analizi. Alınteri Zirai Bilimler Dergisi 28(B) : 19-26. ISSN: 1307-3311.

Dağdemir, V., 1998. Türkiye Soğan Piyasasının Ekonomik Analizi. Atatürk Üniversitesi İktisadi ve İdari Bilimler Dergisi Cilt:12, Sayı:1/2, Sayfa 99114.

Dağdemir, V., Birinci, A., 1999. Türkiye'de Patates Pazarlamas1 ve Fiyat Dalgalanmalarını Üretim Üzerine Etkisi. II. Ulusal Patates Kongresi, 28 - 30 Haziran, Erzurum.

Demirbaş, N., Niyaz, Ö.C., Daysal, H., 2017. Evaluation of self-sufficiency in lentil production in Turkey.

GOP Ziraat Fakültesi Dergisi.

Hasdemir, M., Miran, B., Kandemir, M., Polat, K., 2016. Baklagil Üretiminde Fark Ödemesi Desteklerinin Etkisi. TEPGE Yayın No:265.

Gülaç, Z.N., 2017. Mercimek Ürün Raporu, TEPGE Yayın No:306.

Karadaş, K., Bakçı, C., Kadirhanoğulları, İ.H., 2018. Midyat İlçesi Tarım İşletmelerinde Mercimek Üretim

Maliyetinin Hesaplanmasi. Atatürk Üniversitesi Ziraat Fakültesi Dergisi., 49 (2): 118-123, 2018 
Atatürk Üniversitesi, J. of the Agricultural Faculty, 49 (2): 118-123, 2018 ISSN : 1300-9036.

Kaya, F., 2010. Ülkemizde Yetiştirilen Bazı Mercimek Çeşitlerinin Bileşimlerinin Belirlenmesi. Ç.Ü. Ziraat Fakültesi. Yüksek Lisans Tezi. Adana. 59s.

Kılıç, T., 1997. Türkiye'de Yemeklik Baklagil Üretim Tüketim Ticaret ve Dışsatım Pazarlama Yapısı. Ç.Ü.
Fen Bilimleri Enstitüsü Tarım Ekonomisi Anabilim Dalı Yüksek Lisans Tezi. Adana.

Pellet, P., 1988. İnsan Beslenmesinde Mercimek ve Nohutun Yeri. Herkes İçin Mercimek Sempozyumu, 29-30 Eylül 1988, Marmaris, TMO yayınları, sayfa: 37-135, Ankara. 